\title{
KOMPARASI KAPASITAS NOMINAL LENTUR PELAT KOMPOSIT BETON-DEK BAJA ANTARA METODE ULITMIT, TEGANGAN KERJA, DAN SDI-ANSI 2017
}

\author{
Hariadi Yulianto ${ }^{1, *)}$ \\ ${ }^{1, *)}$ Jurusan Teknik Sipil, Fakultas Teknik Sipil dan Perencanaan, Universitas Islam Indonesia \\ Email: hariadi.yulianto@uii.ac.id
}

\begin{abstract}
Today, the most efficient slab construction method is the concrete-steel deck composite slab because there is no need to remove the deck after the concrete casting process. Nevertheless, the reinforced concrete standard code (SNI 2847:2019) does not emphasize a specific method to calculate the concrete-steel deck slab's nominal capacity. The code is embraced by the plastic method analysis, which is calculated the nominal capacity of the structure on the ultimate condition. However, several laboratory tests reveal slip behavior between the concrete and steel deck before the slab reaches its ultimate condition. Therefore, alternative methods are needed to analyze the nominal capacity of concrete-steel deck slabs. This study compares three different analysis methods of nominal capacity to the laboratory test results. Those methods are ultimate, working stress, and SDI-ANSI (2017). The average error values of those three methods are compared to the laboratory test results in $35.57 \%, 9.48 \%$, and $-10.31 \%$ for ultimate, working stress, SDI-ANSI (2017) consecutively. It can be concluded that the working stress method is the most accurate. However, SDI-ANSI (2017) is the conservative one, while the ultimate method is not recommended to analyze the concrete-steel deck slabs of nominal capacity.
\end{abstract}

Keywords: concrete-steel deck composite slab, nominal capacity, ultimate, working stress, SDIANSI 2017

\section{PENDAHULUAN}

Pelat lantai komposit beton-dek baja merupakan metode konstruksi pelat lantai yang paling efisien, bahkan lebih efisien daripada sistem pelat pra-cetak metode half slab (Fastaria dan Putri, 2014). Hal ini dikarenakan tidak perlunya melepas dek baja gelombang pasca proses pengecoran beton yang berfungsi sebagai pengganti tulangan positif sekaligus sebagai cetakan lantai (Widhiawati et al., 2010). Namun demikian, dalam standar struktur beton bertulang (SNI 2847:2019) belum terdapat tata cara yang spesifik mengenai perhitungan kapasitas nominal lentur dari pelat komposit beton-dek baja.

Pada dasarnya, SNI 2847:2019 menggunakan metode analisis plastis untuk menganalisis kapasitas nominal struktur berdasarkan kondisi ultimate-nya (dek baja telah leleh sepenuhnya). Namun beberapa penelitian mengenai pelat komposit beton-dek baja yang telah dilakukan oleh Muliater et al. (2018), Irnada et al. (2014), Amalia et al. (2014), serta Kadir dan Sudarmadi (2008) mengungkapkan adanya fenomena slip antara beton dengan dek baja sebelum kondisi ultimate tercapai. Oleh karena itu, diperlukan metode alternatif lainnya untuk menganalisis kapasitas nominal dari pelat komposit beton-dek baja.

Alternatif selain metode ultimate untuk menganalisis kapasitas nominal pelat betondek baja adalah metode tegangan kerja dan SDI-ANSI (Steel Deck Institute - American National Standard Institute) 2017. Kedua metode ini menganalisis kekuatan lentur pelat komposit beton-dek baja berdasarkan kondisi tegangan leleh $\left(f_{y}\right)$ dari material dek baja pada serat terluarnya (first yield condition). Oleh karena itu, studi ini bertujuan untuk mengkomparasi hasil analisis kapasitas nominal lentur pelat komposit beton-dek baja 
dari ketiga metode tersebut (metode ultimate, tegangan kerja, dan SDI-ANSI) terhadap hasil pengujian laboratorium di Indonesia sehingga dapat dijadikan dasar dalam pengembangan standar struktur beton bertulang Indonesia di masa yang akan datang.

\section{Metode Ultimate}

Asumsi yang digunakan pada metode ultimate pada kondisi momen positif adalah dek baja menahan gaya tarik dan beton akan menahan gaya tekan seperti yang ditunjukkan Gambar 1 (Siregar, 2010).

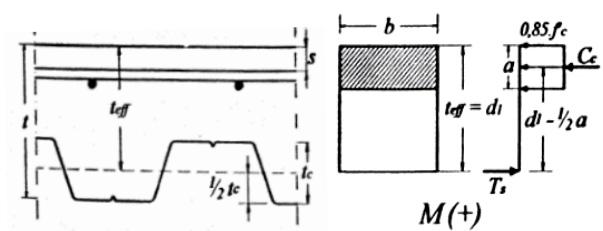

Gambar 1. Asumsi penampang dan gayagaya dalam pelat beton-dek baja (Siregar, 2010)

Gaya tarik yang bekerja pada penampang dek baja diasumsikan memiliki resultan pada titik beratnya $\left(1 / 2 t_{c}\right)$ dan dek baja berada dalam kondisi leleh sepenuhnya (plastic condition), sehingga kapasitas nominalnya dapat dilihat pada persamaan (1).

$M_{n}=A_{s} \times f_{y}\left(d_{1}-\frac{A_{s} \times f_{y}}{2 \times 0,85 \times f_{c}^{\prime} \times b}\right) \times 10^{-6}$

dengan,

$M_{n}=$ kapasitas lentur $(\mathrm{kNm})$,

$A_{s}=$ luas penampang dek baja $\left(\mathrm{mm}^{2}\right)$,

$f_{y}=$ tegangan leleh dek baja (MPa),

$d_{l}=$ jarak antara titik berat baja dek sampai ke serat terluar tekan,

$d_{l}=t-1 / 2 t c=t_{\text {eff }}$,

$\mathrm{t}=$ adalah tebal pelat $(\mathrm{mm})$,

$f_{c}{ }^{\prime}=$ mutu beton $(\mathrm{MPa})$,

$b=$ lebar satuan pelat $(1000 \mathrm{~mm})$.

\section{Metode Tegangan Kerja}

Prinsip dari metode tegangan kerja adalah menganalisis kapasitas lentur pelat komposit beton-dek baja pada kondisi tegangan leleh $\left(f_{y}\right)$ dek baja pada serat terluarnya (first yield condition). Pada metode ini, penampang pelat berperilaku komposit antara beton-dek baja (penampang transformasi) namun dengan kondisi beton tarik telah retak (cracked section properties). Asumsi penampangnya dapat dilihat pada Gambar 2 dengan kapasitas nominalnya dapat dilihat pada persamaan (2).

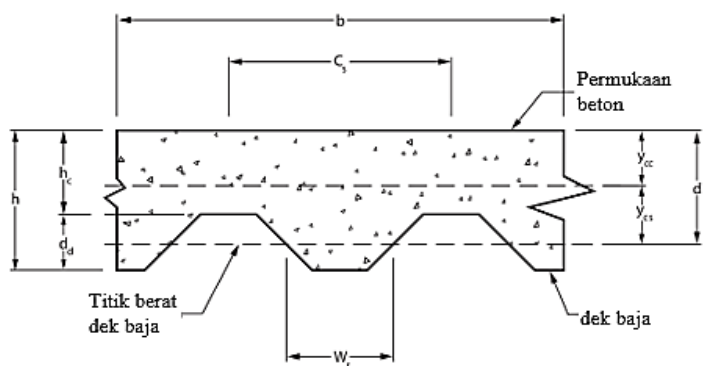

Gambar 2. Asumsi penampang komposit beton-dek baja

$M_{n}=\frac{f_{y} \times I_{c r}}{n \times\left(h-y_{c c}\right)} \times 10^{-6}$

dengan,

$M_{n}=$ kapasitas lentur $(\mathrm{kNm})$,

$f_{y}=$ tegangan leleh dek baja (MPa),

$h=$ ketebalan pelat beton total ( $\mathrm{mm})$,

$y_{c c}=$ garis netral penampang retak $(\mathrm{mm})$,

$I_{c r}=$ inersia penampang retak $\left(\mathrm{mm}^{4}\right)$,

$\mathrm{n}=$ rasio modulus elastisitas dek baja terhadap beton $\left(E_{s} / E_{c}\right)$.

\section{Inersia Penampang Komposit Retak}

Perhitungan inersia penampang retak berawal dari perhitungan tinggi garis netralnya $\left(y_{c c}\right)$. Penampang beton tarik dianggap tidak bekerja sehingga letak garis netral $\left(y_{c c}\right)$ ditentukan dengan menyamakan statis momen luasan beton tekan dan luas dek baja tarik transformasi $\left(\mathrm{n} \times A_{s}\right)$. Dengan penampang sama seperti Gambar 2, maka nilai $y_{c c}$ dapat dilihat pada persamaan (3).

$b \times y_{c c} \times \frac{1}{2} y_{c c}=n \times A_{s} \times\left(d-y_{c c}\right)$

Nilai $y_{c c}$ diperoleh dengan mencari akar-akar persamaan dari persamaan (3). Setelah diperoleh nilai $y_{c c}$, maka inersia penampang komposit retak diperoleh dengan menggunakan persamaan (4).

$I_{\mathrm{t}}=\frac{1}{3} \times b \times y_{c c}^{3}+n \times\left(I_{s d}+\mathrm{A}_{\mathrm{s}} \times y_{c s}{ }^{2}\right)$

dengan, 
$I_{\mathrm{sd}} \quad=$ inersia penampang dek baja $\left(\mathrm{mm}^{4}\right)$.

\section{Metode SDI-ANSI}

Metode SDI-ANSI menghitung kekuatan lentur pelat beton-dek baja per 12 inci lebar pelat dengan asumsi penampang sama seperti Gambar 2. Kapasitas nominalnya juga dihitung pada kondisi first yield dengan direduksi faktor " $k$ " yang merupakan pengaruh dari tipe sirip dek baja (deck embossment), sehingga perhitungan kapasitas nominalnya dapat dilihat pada persamaan (5) sampai persamaan (10) (SDI-ANSI, 2017).

$M_{n}=k \times f_{y} \times \frac{I_{c r}}{\left(h-y_{c c}\right)}$

dengan,

$I_{c r}=\frac{b}{3 n} \times y_{c c}^{3}+A_{s} \times y_{c s}^{2}+I_{s f}$,

$I_{s f}=$ inersia penampang dek baja $\left(\right.$ inci $\left.^{4}\right)$,

$y_{c c}=d \times\left(\sqrt{2 \times \rho \times n+(\rho \times n)^{2}}-\rho n\right)$,

$\rho=\frac{A_{s}}{b \times d}$

$K=K_{3} / K_{1} \leq 1,0$,

$K_{3}=0,87+0,0688 \times \mathrm{N}-0,00222 \times \mathrm{N}^{2} \leq 1,4,(10)$

$N$ adalah jumlah gelombang dek baja dalam arah lebar pelat. $K_{l}$ adalah faktor tipe sirip dek baja, dimana produk SMARTDECK memiliki tipe sirip mendekati tipe 1 dari SDI-ANSI, sehingga nilai $K_{l}$ (SDI-ANSI, 2017) dapat dilihat pada persamaan (11).

$K_{l}=0,07 \times \frac{D_{w}^{0,5}}{p_{h}}$,

dengan,

$D_{w}=$ lebar puncak gelombang dek baja (inci),

$P_{h}=$ ketinggian sirip dek baja (inci).

\section{DATA SEKUNDER PENELITIAN}

Data skunder yang digunakan dalam studi ini berasal dari publikasi yang ditulis oleh Kadir dan Sudarmadi (2008). Benda uji lentur pelat komposit beton-dek baja sejumlah 3 buah (benda uji A, B, dan C) dengan dimensi dek baja $2,01 \mathrm{~m} \times 1000 \mathrm{~mm} \times 0,8 \mathrm{~mm}(0,7 \mathrm{~mm}$ base metal dan $0,1 \mathrm{~mm}$ galvanized $)$ mutu baja $f_{y}=$ $400 \mathrm{MPa}$ dengan $\varepsilon_{\mathrm{y}}=2000 \mu \varepsilon$. Tebal pelat komposit beton-dek baja adalah $13 \mathrm{~cm}$. Tulangan susut diameter $10 \mathrm{~mm}$ dipasang pada sisi atas dan bawah penampang. Penampang benda uji dapat dilihat pada Gambar 3. Dimensi dan properti penampang dek baja mengacu pada produk SMARTDECK yang ditunjukkan pada Gambar 5 dan Tabel 1. Mutu beton pelat diuji menggunakan hammer test dengan hasil berturut-turut untuk benda Uji $\mathrm{A}, \mathrm{B}$, dan $\mathrm{C}$ adalah $16 \mathrm{MPa}$, 12,3 MPa, dan 12,7 MPa.

Pelat diuji dengan pengujian lentur murni menggunakan pembebanan 2 titik dengan pengukuran lendutan dan regangan pada tengah bentang pelat. Pembebanan dilakukan dengan jarak $705 \mathrm{~mm}$ dari tepi tumpuan dan jarak antar beban titik $500 \mathrm{~mm}$ seperti yang diilustrasikan dalam Gambar 4 dengan hasil pengujian dapat dilihat pada Tabel 2 .

Hubungan beban-lendutan yang didapatkan dari pengujian menunjukkan seluruh benda uji mengalami slip (Gambar 6 dan Gambar 7). Hal ini ditunjukkan dengan adanya penurunan beban uji secara tiba-tiba diikuti dengan lendutan balik ke atas. Kapasitas nominal pelat komposit beton-dek baja hasil pengujian diambil sebagai momen lentur akibat gaya uji pada kondisi slip.

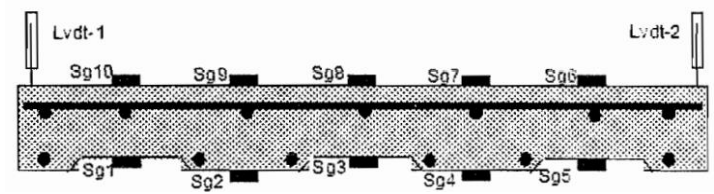

Gambar 3. Penampang benda uji (Kadir dan Sudarmadi, 2008)

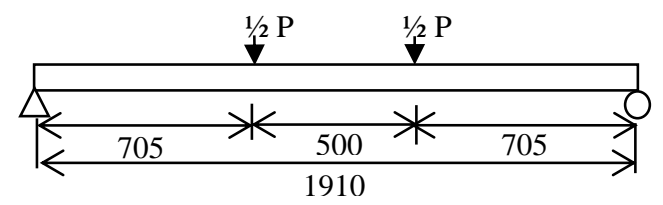

Gambar 4. Ilustrasi set up pengujian lentur pelat (Kadir dan Sudarmadi, 2008) 


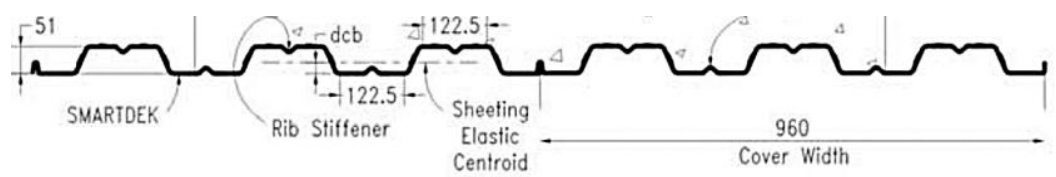

Gambar 5. Dimensi SMARTDECK (Blue Scope Lysagth Indonesia, 2008)

Tabel 1. Properti penampang SMARTDECK (Blue Scope Lysagth Indonesia, 2008)

\begin{tabular}{|c|c|c|c|c|c|}
\hline \multirow{2}{*}{ Properti } & \multirow{2}{*}{ Unit } & \multirow{2}{*}{ Simbol } & \multicolumn{3}{|c|}{ Base Metal Thickness (BMT) (mm) } \\
\cline { 4 - 6 } & & & 0,7 & 1,0 & 1,2 \\
\hline Area & $\mathrm{mm}^{2} / \mathrm{m}$ & $A$ & 889,69 & 1143,75 & 1523,96 \\
\hline Inertia moment & $\mathrm{mm}^{4} / \mathrm{m}$ & $I_{x}$ & 409687,50 & 526562,50 & 701979,17 \\
\hline Section Modulus & $\mathrm{mm}^{3} / \mathrm{m}$ & $Z_{x}$ & 15156,25 & 19479,17 & 25958,33 \\
\hline Mass & $\mathrm{Kg} / \mathrm{m}^{2}$ & $W$ & 7,35 & 9,34 & 12,33 \\
\hline
\end{tabular}

Tabel 2. Hasil uji lentur pelat komposit beton-dek baja (Kadir dan Sudarmadi, 2008)

\begin{tabular}{|l|c|c|c|c|c|}
\hline \multicolumn{1}{|c|}{ Jenis uji } & $\begin{array}{c}\text { Beban } \\
\text { uji }(\mathrm{kN})\end{array}$ & $\begin{array}{c}\text { Reg. maks pada } \\
\text { metal deck }(\mu \varepsilon)\end{array}$ & $\begin{array}{c}\text { Reg. maks } \\
\text { beton }(\mu \varepsilon)\end{array}$ & $\begin{array}{c}\text { Lendutan } \\
\text { maks }(\mathrm{mm})\end{array}$ & $\begin{array}{c}\text { Ekivalensi beban } \\
\text { merata }\left(\mathrm{kg} / \mathrm{m}^{2}\right)\end{array}$ \\
\hline Pengecoran beton & & & & \\
\hline Benda Uji A & 367 & 342 & & $-6,69$ & \\
\hline Benda Uji B & 367 & & $-11,08$ & \\
\hline Benda Uji C & & & & $-8,28$ & \\
\hline Rata-rata & & 358,6 & & $-7,4$ & 5660 \\
\hline Benda Uji A & & 1821 & -1026 & $-20,19$ & 7124 \\
\hline -Slip & 74,26 & 2023 & -2079 & & \\
\hline -Maksimum & 93,47 & & & -1083 & \\
\hline Benda uji B & & 1574 & -2492 & $-22,17$ & 5610 \\
\hline -Slip & 63,97 & 2088 & & & \\
\hline -Maksimum & 73,61 & & -837 & $-6,17$ & \\
\hline -benda uji C & & 1227 & -3876 & $-29,12$ & 7666 \\
\hline -slip & 53,35 & 3382 & & & \\
\hline -maskimum & 100,53 & & -982 & $-7,14$ & \\
\hline Rata-rata & & 1540 & -2815 & $-23,82$ & 6867 \\
\hline -slip & 63,86 & 2497 & & \\
\hline -maksimum & 89,20 & & & & \\
\hline
\end{tabular}

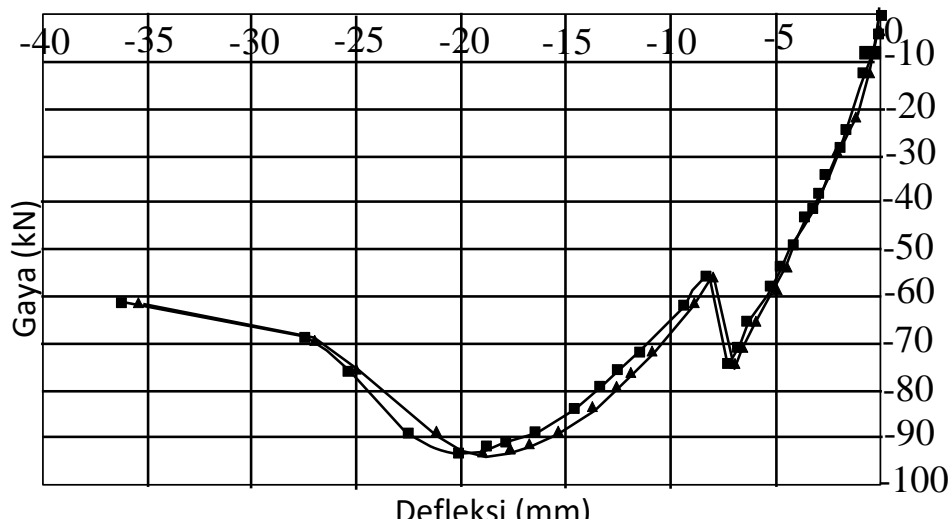

Defleksi (mm)

$\rightarrow$ lvdt-1 $\rightarrow$ - lvdt-2

Gambar 6. Beban-lendutan benda uji A (Kadir dan Sudarmadi, 2008) 

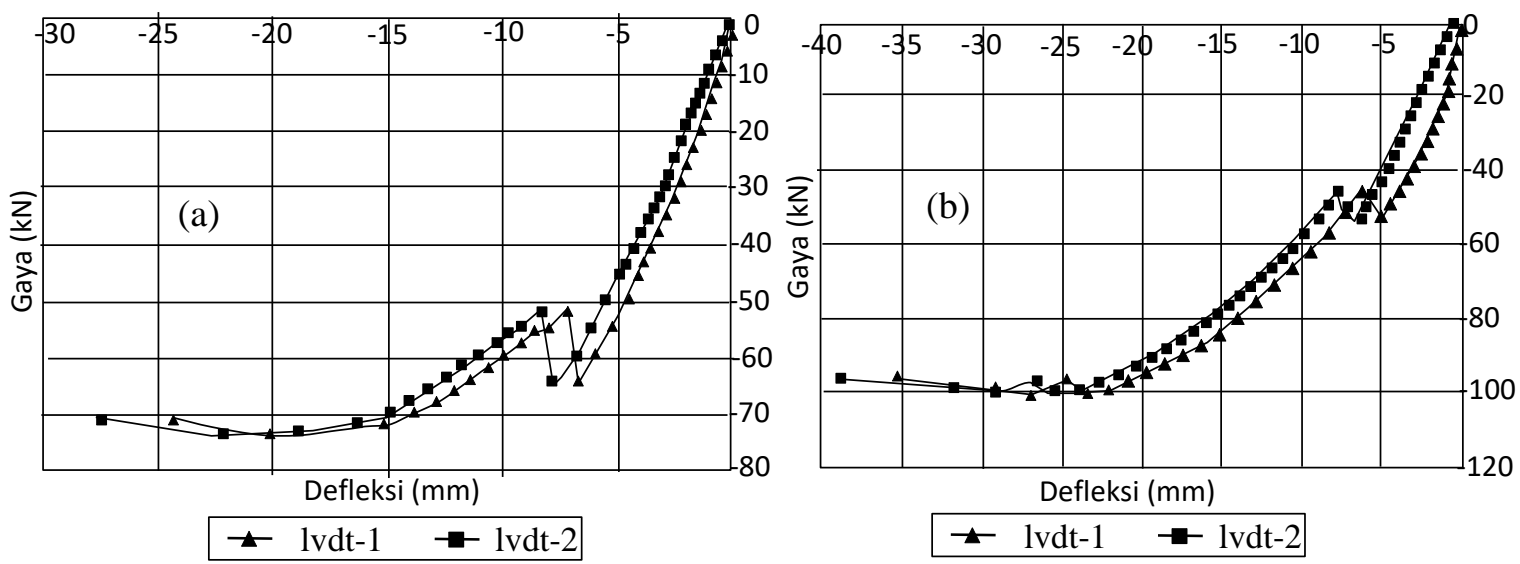

Gambar 7. Beban-lendutan:(a) benda uji B, (b) benda uji C (Kadir dan Sudarmadi, 2008)

\section{ANALISIS DAN PEMBAHASAN}

\section{Perilaku Beban Lendutan}

Berdasarkan Gambar 6 dan Gambar 7, perilaku beban-lendutan dari ke tiga sampel benda uji memiliki hasil yang konsisten. Pada bagian awal pembebanan menghasilkan grafik berupa garis yang relatif lurus. Hal ini menandakan beton-dek baja bekerja sebagai satu kesatuan material komposit yang berperilaku elastis. Selanjutnya hingga terjadi garis yang patah (beban turun sedikit) menunjukan terjadinya slip antara beton dengan dek baja sehingga setelah titik ini beton dan dek baja tidak lagi komposit dan bersifat elastis lagi. (Kadir dan Sudarmadi, 2008).

Setelah titik slip, ketiga benda uji mengalami peningkatan kekuatan yang hingga kondisi maksimum secara parabolik. Hal ini berarti setelah terjadi slip, masih terdapat lekatan antara beton-dek baja hingga tercapai kondisi maksimal. Menurut Widjaja (1997) dalam penelitiannya mengenai perilaku lekatan beton-dek baja, hal ini terjadi karena adanya perilaku lekatan mekanikal dan friksi antara permukaan beton dengan embossment dek baja. Lekatan ini muncul setelah terjadi kegagalan lekatan kimiawi antara pasta semen dengan agregat beton-dek baja. Lekatan kimiawi menghasilkan perilaku beban-slip yang relatif linear hingga terjadi penurunan beban secara tiba-tiba yang (kondisi slip).
Setelah kegagalan kimiawi, lekatan antara beton-dek baja akan kembali meningkat hingga mencapai nilai puncaknya.

\section{Kapasitas Momen lentur Pelat Komposit Beton-Dek Baja Hasil Uji Lab}

Berdasarkan perilaku beban-lendutan dari ketiga benda uji, Kadir dan Sudarmadi (2008) mengambil nilai kuat lentur pelat berdasarkan nilai beban slip hasil pengujian laboratorium, sehingga diharapkan kekuatan pelat pada kondisi kompositnya saja. Berikut ini analisis momen lentur pada beban slip hasil pengujian lentur:

Dengan berat dek baja $7,35 \mathrm{~kg} / \mathrm{m}^{2}$ (Tabel 1) dan luas penampang pelat komposit betondek baja berupa luas penampang pelat utuh dikurangi luas trapesium yang yang hilang (akibat dek baja gelombang) $A=105520 \mathrm{~mm}^{2}$ (Gambar 3) maka berat pelat komposit betondek baja:

Dek baja $=7,35 \times \frac{1910 \times 1000 \times 9,81}{10^{9}}=0,137 \mathrm{kN}$,

Pelat beton $=24 \times \frac{105520 \times 1910}{10^{9}}=4,837 \mathrm{kN}$,

Beban merata equivalent

$q_{D L}=\frac{(4,837+0,137)}{1,910}=2,60 \mathrm{kN} / \mathrm{m}$,

Momen akibat berat sendiri

$M_{D L}=\frac{1}{8} \times 2,60 \times 1,91^{2}=1,187 \mathrm{kNm}$. 
Berdasarkan set up pengujian pada Gambar 4 maka momen lentur akibat beban uji dapat dihitung menggunakan persamaan (12).

$M_{L L}=\frac{\frac{1}{2} P \times 705}{1000}(\mathrm{kNm})$

Sehingga momen lentur gabungan antara beban slip dan berat mat sendiri dapat dilihat pada Tabel 3 .

Tabel 3. Momen lentur hasil pengujian

\begin{tabular}{|c|c|c|c|}
\hline No & Benda Uji & $\begin{array}{c}\text { Beban Slip } \\
(\mathrm{kN})\end{array}$ & $\begin{array}{c}M_{D L}+M_{L L} \\
(\mathrm{kNm})\end{array}$ \\
\hline 1 & A & 74,26 & 27,36 \\
\hline 2 & B & 63,97 & 23,74 \\
\hline 3 & C & 53,35 & 19,99 \\
\hline 4 & Rata-Rata & 63,86 & 23,70 \\
\hline
\end{tabular}

\section{Modulus Elastisitas Beton}

Nilai modulus elastisitas beton pada benda uji pelat komposit beton-dek baja $\left(E_{c}\right)$ ditentukan dengan menggunakan persamaan (13) (BSN, 2019).

$E_{c}=4700 \sqrt{f_{c}^{\prime}}$

dengan,

$f_{c}{ }^{\prime}=$ kuat tekan beton (MPa).

$f_{c}$ ' dari hammer test dimasukan ke dalam persamaan (13) kemudian dihitung rasio modulus (n) terhadap modulus elastisitas baja dengan hasil sebagaimana Tabel 4.

Tabel 4. Nilai $E_{c}$ dan rasio modulus

\begin{tabular}{|l|c|c|c|}
\hline Benda Uji & $f_{c}{ }^{\prime}(\mathrm{MPa})$ & $E_{c}(\mathrm{MPa})$ & $\begin{array}{c}\mathrm{n} \\
(\mathrm{Es} / \mathrm{Ec})\end{array}$ \\
\hline Pelat A & 16,0 & 18800,0 & 10,64 \\
\hline Pelat B & 12,3 & 16483,5 & 12,13 \\
\hline Pelat C & 12,7 & 16749,4 & 11,94 \\
\hline
\end{tabular}

Metode Tegangan Kerja

Dengan asumsi penampang komposit seperti Gambar 2 serta dimensi mengacu pada Gambar 3, Gambar 5, dan Tabel 1, titik berat serta tebal efektif (d) dari pelat komposit ditunjukkan pada Tabel 4. Kemudian, seluruh data pada Tabel 4 dan Tabel 4 dimasukkan ke dalam persamaan (3) sehingga diperoleh persamaan kuadrat $y_{c c}$ untuk pelat $\mathrm{A}, \mathrm{B}$, dan $\mathrm{C}$ dengan akar persamaan $y_{c c}$ ditunjukkan pada
Tabel 5. Selanjutnya dari nilai $y_{c c}$, rasio modulus $(n)$, luas tampang dek baja $\left(A_{s}\right)$, serta inersia dek baja $\left(I_{s d}\right)$ dimasukkan ke dalam persamaan (4) sehingga diperoleh inersia pelat komposit retak $\left(I_{c r}\right)$. Analisis penampang dan inersia penampang retak $\left(I_{c r}\right)$ berturut-turut dapat dilihat pada Tabel 5 dan Tabel 6.

Tabel 5. Analisis penampang

\begin{tabular}{|l|c|}
\hline \multicolumn{1}{|c|}{ Parameter } & Analisis \\
\hline Titik berat dek baja & $1 / 2 \times 51=25,5 \mathrm{~mm}$ \\
\hline Tebal efektif $(d)$ & $d=130-25,5=104,5 \mathrm{~mm}$ \\
\hline Lebar pelat & $b=1000 \mathrm{~mm}$ \\
\hline Luas tampang dek & $A_{s}=889,69 \mathrm{~mm}^{2}$ \\
\hline Inersia dek baja & $I_{s d}=409687,5 \mathrm{~mm}^{4}$ \\
\hline
\end{tabular}

Tabel 6. Inersia penampang retak $\left(I_{c r}\right)$

\begin{tabular}{|l|c|c|c|}
\hline \multirow{2}{*}{ Parameter } & \multicolumn{3}{|c|}{ Benda Uji Pelat } \\
\cline { 2 - 4 } & A & B & C \\
\hline$y_{c c}(\mathrm{~mm})$ & 36,01 & 37,92 & 37,68 \\
\hline$d(\mathrm{~mm})$ & 104,5 & 104,5 & 104,5 \\
\hline$y_{c s}(\mathrm{~mm})$ & 68.49 & 66.58 & 66.82 \\
\hline$b(\mathrm{~mm})$ & 1000 & 1000 & 1000 \\
\hline$n$ & 10,64 & 12,13 & 11,94 \\
\hline$A_{s}\left(\mathrm{~mm}^{2}\right)$ & 889,69 & 889,69 & 889,69 \\
\hline$I_{s d}\left(\mathrm{~mm}^{4}\right)$ & 409687,5 & 409687,5 & 409687,5 \\
\hline$I_{c r}\left(\mathrm{~mm}^{4}\right)$ & $64,3 \times 10^{6}$ & $70,9 \times 10^{6}$ & $70,16 \times 10^{6}$ \\
\hline
\end{tabular}

\section{Metode SDI-ANSI}

Pada metode SDI-ANSI dimana perhitungan dilakukan per 12 inci lebar pelat, diperoleh garis netral penampang $\left(y_{c c}\right)$ dengan menggunakan persamaan (7). Kemudian nilai $y_{c c}, A_{s}, I_{s f}$, serta " $n$ " dimasukkan ke dalam persamaan (6) sehingga diperoleh inersia penampang komposit retak $\left(I_{c r}\right)$ yang dapat dilihat pada Tabel 7.

Tabel 7. Inersia penampang retak $\left(I_{c r}\right)$ per 12 inci lebar pelat metode SDI-ANSI

\begin{tabular}{|l|c|c|c|}
\hline \multirow{2}{*}{ Parameter } & \multicolumn{3}{|c|}{ Benda Uji Pelat } \\
\cline { 2 - 4 } & A & B & C \\
\hline$y_{c c}(\mathrm{~mm})$ & 36,32 & 38,35 & 38,10 \\
\hline$d(\mathrm{~mm})$ & 105,003 & 105,003 & 105,003 \\
\hline$y_{c s}(\mathrm{~mm})$ & 68,58 & 66,80 & 67,05 \\
\hline $\mathrm{b}(\mathrm{mm})$ & 304,8 & 304,8 & 304,8 \\
\hline$n$ & 10,82 & 12,34 & 12,14 \\
\hline$A_{s}\left(\mathrm{~mm}^{2}\right)$ & 10,67 & 10,67 & 10,67 \\
\hline$I_{s f}\left(\mathrm{~mm}^{4}\right)$ & 7,62 & 7,62 & 7,62 \\
\hline$I_{c r}\left(\mathrm{~mm}^{4}\right)$ & 113,03 & 109,474 & 109,982 \\
\hline
\end{tabular}

Teknisia, Volume XXVI, No 1, Mei 2021 


\section{Analisis Kapasitas Nominal Lentur Pelat Komposit Beton-Dek baja}

\section{Metode ultimate}

Kapasitas nominal lentur pelat dengan metode ultimate dihitung menggunakan persamaan (1), dengan memasukkan nilai mutu beton yang mengacu pada Tabel 3 , lebar pelat $(b)=$ $1000 \mathrm{~mm}$, tinggi efektif $\left(d_{l}\right)=104,5 \mathrm{~mm}$ luas tampang dek baja $\left(\mathrm{A}_{\mathrm{s}}\right)=889,69 \mathrm{~mm}^{2}$ dan mutu baja $\left(f_{y}\right)=400 \mathrm{MPa}$. Hasil Kapasitas momen lentur ultimate dapat dilihat pada Tabel 8.

Tabel 8. Kapasitas momen lentur ultimate

\begin{tabular}{|c|c|c|}
\hline No & Benda Uji & $M_{n}(\mathrm{kNm})$ \\
\hline 1 & $\mathrm{~A}$ & 32,53 \\
\hline 2 & $\mathrm{~B}$ & 31,13 \\
\hline 3 & $\mathrm{C}$ & 31,32 \\
\hline & Rata-Rata & 31,74 \\
\hline
\end{tabular}

2. Metode tegangan kerja

Analisis kapasitas nominal lentur metode tegangan kerja dilakukan dengan memasukkan nilai inersia penampang retak $\left(I_{c r}\right)$, rasio modulus $(n)$, tebal pelat $(h)$ serta mutu dek baja $f_{y}=400 \mathrm{MPa}$ ke dalam persamaan (2) dengan hasil dapat dilihat pada Tabel 9.

Tabel 9. Momen lentur tegangan kerja

\begin{tabular}{|c|c|c|}
\hline No & Benda Uji & $M_{n}(\mathrm{kNm})$ \\
\hline 1 & A & 25,73 \\
\hline 2 & B & 25,42 \\
\hline 3 & C & 25,46 \\
\hline & Rata-rata & 25,54 \\
\hline
\end{tabular}

\section{Metode SDI-ANSI}

Berdasarkan brosur produk SMARTDECK, sirip pada dek baja termasuk katergori sirip tipe 1 pada SDI-ANSI dengan lebar puncak gelombang dek $D_{w}=122,5 \mathrm{~mm}$ dan tinggi sirip dek $P_{h}=3,0 \mathrm{~mm}$, jumlah glombang searah lebar pelat berdasarkan Gambar $5(N)=3$. Faktor $\mathrm{K}_{3}$ diperoleh dengan memasukan nilai $N=3$ ke dalam persamaan (10) sehingga diperoleh nilai $\mathrm{K}_{3}=1,06$. Selanjutnya dengan memasukan nilai $D_{w}$ dan $P_{h}$ ke dalam persamaan (11) diperoleh nilai $K_{l}=1,302$. Kemudian nilai $K_{3}$ dan $\mathrm{K}_{1}$ dimasukan ke persamaan (9) diperoleh faktor $K=0,812$. Dengan memasukkan nilai inersia penampang retak $\left(I_{c r}\right)$, " $n$ ", tebal pelat $(h)$, mutu baja $\left(f_{y}\right)$ dan faktor $K$ hasil perhitungan sebelumnya ke dalam persamaan (5) diperoleh kapasitas nominal lentur pelat komposit beton-dek baja per 12 inci lebar pelat dan konversi ke $1 \mathrm{~m}$ lebar pelat yang dapat dilihat pada Tabel 10 .

Tabel 10. Kapasitas momen lentur SDIANSI

\begin{tabular}{|c|c|c|c|}
\hline \multirow{2}{*}{ No } & \multirow{2}{*}{ Benda Uji } & \multicolumn{2}{|c|}{$M_{n}(\mathrm{kNm})$} \\
\cline { 3 - 4 } & & Per 12 inci & Per $1 \mathrm{~m}$ \\
\hline 1 & A & 7,914 & 25,97 \\
\hline 2 & B & 7,819 & 25,66 \\
\hline 3 & C & 7,830 & 25,69 \\
\hline & Rata-Rata & 7,854 & 25,07 \\
\hline
\end{tabular}

4. Validasi metode analisis kapasitas lentur

Metode analisis kapasitas lentur pelat komposit beton-dek baja divalidasi dengan membandingkannya terhadap hasil uji lentur laboratorium. Hasilnya berupa persentase nilai error hasil analisis terhadap hasil uji laboratorium yang ditunjukkan pada Tabel 15. Nilai positif (+) menunjukkan nilai kapasitas lentur hasil analisis lebih besar dari hasil uji laboratorium, sebaliknya nilai negatif (-) menunjukkan nilai hasil analisis lebih kecil dari hasil uji laboratorium. Secara umum terlihat bahwa metode tegangan kerja paling akurat dengan nilai rerata error paling kecil, namun metode SDI-ANSI paling konservatif dengan nilai error yang negatif.

Jika dilihat nilai regangan dek baja pada Tabel 2 saat beban slip, regangan total (berat beton + beban uji) pelat $\mathrm{A}, \mathrm{B}$, dan $\mathrm{C}$ berturut turut adalah: $\varepsilon_{\mathrm{s}}=2188 \mu \varepsilon, \varepsilon_{\mathrm{s}}=1916 \mu \varepsilon$, dan $\varepsilon_{\mathrm{s}}=1594$ $\mu \varepsilon$. Hal ini berarti dek baja pada pelat A telah leleh karena $\left(\varepsilon_{\mathrm{s}}\right)>\varepsilon_{\mathrm{y}}\left(\varepsilon_{\mathrm{y}}=2000 \mu \varepsilon\right)$. Pelat B hampir mencapai leleh, sedangkan pelat $\mathrm{C}$ belum leleh. Namun jika melihat nilai error metode tegangan kerja lebih rendah dari metode ultimate, maka dapat disimpulkan kondisi yang terjadi pada benda uji adalah kondisi first yield (dek baja leleh pada serat terluarnya saja), bukan kondisi plastis (seluruh penampang dek baja leleh). 
Tabel 11. Nilai error hasil analisis terhadap hasil uji laboratorium

\begin{tabular}{|c|c|c|c|c|c|c|c|c|c|}
\hline \multirow[b]{2}{*}{ Benda Uji } & \multirow[b]{2}{*}{$\begin{array}{c}\text { Regangan } \\
\text { dek baja } \\
\left(\mu_{\varepsilon}\right)\end{array}$} & \multirow[b]{2}{*}{$\begin{array}{l}\text { Mutu } \\
\text { beton } \\
(M P a)\end{array}$} & \multirow[b]{2}{*}{$\begin{array}{c}\text { lentur } \\
\text { uji } \\
(k N m)\end{array}$} & \multicolumn{6}{|c|}{ Momen nominal } \\
\hline & & & & $\begin{array}{l}\text { Ultimate } \\
(\mathrm{kNm})\end{array}$ & $\begin{array}{c}\text { Error } \\
(\%)\end{array}$ & $\begin{array}{c}\text { Tegangan } \\
\text { kerja } \\
(k N m)\end{array}$ & $\begin{array}{c}\text { Error } \\
(\%)\end{array}$ & $\begin{array}{l}\text { SDI- } \\
\text { ANSI } \\
(k N m)\end{array}$ & $\begin{array}{c}\text { Error } \\
(\%)\end{array}$ \\
\hline A & 2188 & 16,0 & 27,36 & 32,53 & 18,89 & 25,73 & $-5,97$ & 21,08 & $-22,97$ \\
\hline B & 1916 & 12,3 & 23,74 & 31,13 & 31,15 & 25,42 & 7,08 & 20,82 & $-12,28$ \\
\hline $\mathrm{C}$ & 1594 & 12,7 & 19,99 & 31,32 & 56,67 & 25,46 & 27,33 & 20,85 & 4,31 \\
\hline Rata-rata & & 13,7 & 23,70 & 31,64 & 35,57 & 25,54 & 9,48 & 21,08 & $-10,31$ \\
\hline
\end{tabular}

Tabel 11 menunjukan pola nilai error antara metode SDI-ANSI dan tegangan kerja berkebalikan. Jika metode tegangan kerja akurat pada mutu beton tertinggi kemudian berturut-turut semakin tidak akurat untuk mutu beton rendah $(-5,97 \%$ s.d. $27,33 \%)$, metode SDI-ANSI sebaliknya $(-22,97 \%$ s.d. 4,31\%). Hal ini sejalan dengan kondisi dek baja pelat A yang telah mencapai kondisi first yield dan pelat B yang hampir mencapai first yield. Inilah mengapa metode tegangan kerja cukup akurat pada pelat A dan B karena kondisinya mendekati asumsi perhitungan (first yield), sedangkan pada pelat $\mathrm{C}$ yang jauh dari kondisi first yield metode tegangan kerja menjadi tidak akurat.

Adapun metode SDI-ANSI, faktor " $K$ " mereduksi kekuatan lentur first yield dari pelat komposit beton-dek baja hingga $20 \%$ (nilai $K=0,8$ ), sehingga metode ini akurat pada benda uji $\mathrm{C}$ yang terjadi slip jauh sebelum kondisi first yied, sedangkan benda uji A telah mencapai first yield dan B hampir mencapai first yield, metode ini menjadi tidak akurat. Dengan demikian dapat disimpulkan bahwa faktor " $K$ " pada SDIANSI mengakomodir fenomena slip antara beton dan dek baja sebelum tercapainya kondisi first yield . Faktor " $K$ " inilah yang membuat hasil perhitungan metode SDIANSI paling konservatif dengan rata-rata error $-10,3 \%$. Hasil analisis ini sejalan dengan penelitian yang dilakukan oleh Muliater et al. (2018). Kondisi ultimate (plastis) juga tidak tercapai pada pengujian laboratorium mereka akibat terjadinya slip antara beton dan dek bajanya. Namun dalam analisis kapasitas lentur pelat menggunakan metode SDI-ANSI (2011), menghasilkan nilai kapasitas lentur yang lebih kecil dari hasil uji laboratorium (Muliater et al., 2018). Hal menunjukkan metode SDI-ASNI (2011) juga mengakomodir kondisi slip yang terjadi sebelum kondisi ultimate walaupun SDIANSI (2011) belum menggunakan faktor "K" seperti SDI-ANSI (2017) yang digunakan dalam studi ini.

Jika dihubungkan antara mutu beton dengan regangan pada dek baja, terlihat hanya mutu beton $16 \mathrm{MPa}$ yang mampu mempertahankan lekatan antara beton dan dek baja hingga kondisi first yield sedangkan mutu beton 12,3 dan $12,7 \mathrm{MPa}$ tidak. Ini berarti semakin tinggi mutu beton, semakin kuat lekatan antara beton-dek bajanya. Jika pelat komposit menggunakan mutu beton sesuai syarat minimum SNI 2847:2019 yaitu 20 MPa, diharapkan lekatan antara beton-dek baja bisa bertahan hingga kondisi first yield sehingga metode perhitungan tegangan kerja akan sangat akurat. Namun hal ini perlu penelitian lebih lanjut di laboratorium

\section{Faktor reduksi kekuatan lentur $(\phi)$}

Evaluasi nilai faktor reduksi kuat lentur $(\phi)$ juga dilakukan pada studi analisis ini. Tujuan nya adalah untuk mendapatkan angka faktor keamanan yang reliable antara kapasitas nominal teoritis terhadap hasil uji laboratorium. Menurut Ravindra dan Galambos (1978) dalam Segui (2007) faktor reduksi kekuatan dirumuskan sebagai sebagaimana persamaan (14).

$\phi=\frac{R_{m}}{R_{n}} e^{\left(-0,55 \times \beta \times V_{R}\right)}$ 
$R_{m}=$ nilai rata-rata resistance hasil pengujian,

$R_{n}=$ nilai nominal resistance teoritis,

$\beta=$ index reliability atau safety index,

$V_{R}=$ koefisien variasi dari resistance,

$V_{R}=$ rasio standar deviasi terhadap nilai rata-rata) resistance $\left(\frac{S}{\bar{x}}\right)$.

Berdsarkan standar AISC dalam Segui (2007) nilai safety index ( $\beta$ ) dalam metode LRFD pada kombinasi beban $(\mathrm{D}+\mathrm{L})$ adalah $\beta=3,0$.

Berdasarkan Tabel 11 hasil analisis statistika menghasilkan rata-rata kekuatan lentur hasil uji (Resistance) $R_{m}=23,70 \mathrm{kNm}$ dan standar deviasi $S_{d}=3,01$ sehingga $V_{R}=\frac{3,01}{23,70}=0,127$.

Sebagai contoh diambil perhitungan metode tegangan kerja. Nilai rata-rata resistensi teoritis adalah $\left(R_{n}\right)=25,85 \mathrm{kN}$ sehingga faktor reduksi $(\phi)$ untuk metode tegangan kerja pada pengujian ini adalah:

$\phi=\frac{23,70}{25,58} e^{-0,55 \times 3 \times 0,127}=0,75$

Dengan cara yang sama diperoleh nilai $\phi$ untuk metode-metode lainya yang dapat dilihat pada Tabel 12.

Tabel 12. Faktor reduksi hasil analisis

\begin{tabular}{|c|c|c|c|}
\hline $\begin{array}{l}\text { Faktor } \\
\text { reduksi }\end{array}$ & $\begin{array}{c}\text { Tegangan } \\
\text { kerja }\end{array}$ & $\begin{array}{c}\text { SDI- } \\
\text { ANSI }\end{array}$ & Ultimate \\
\hline$\phi$ & 0,75 & 0,92 & 0,61 \\
\hline
\end{tabular}

Nilai faktor reduksi $(\phi)$ metode tegangan kerja dan ultimate hasil studi ini lebih rendah daripada rekomendasi dari SDI-ANSI (2017) sebesar $\phi=0,85$. Hal ini karena kedua metode tersebut menghasilkan prediksi kuat lentur yang lebih tinggi dari hasil pengujian, sehinggga diperlukan faktor reduksi yang lebih rendah agar menjamin keamanan struktur. Adapun metode SDI-ANSI menghasilkan nilai kapasitas nominal yang lebih rendah dari pengujian sehingga dengan nilai $\phi=0,92$ sekalipun sudah aman.

Jika dibandingkan dengan SNI 2847:2019 yang menetapkan $\phi=0,65$ untuk struktur lentur dengan regangan baja tarik terluar $\left(\varepsilon_{t}\right) \leq$ $\varepsilon_{y}$ (first yield), maka metode tegangan kerja dapat memenuhi peryaratan SNI sedangkan metode ultimate tidak. Hal ini karena nilai $\phi$ tegangan kerja masih lebih tinggi dari 0,65 , sehingga jika digunakan nilai $\phi=0,65$ akan semakin aman. Sebaliknya, metode ultimate menghasilkan nilai $\phi$ yang lebih rendah dari 0,65 sehingga jika digunakan nilai $\phi$ sesuai SNI 28847:2019 struktur masih tidak aman. Dengan demikian dapat disimpulkan bahwa metode ultimate tidak dapat digunakan untuk analisis kapasitas nominal pelat komposit beton-dek baja.

Adapun metode SDI-ANSI dapat digunakan sebagai alternatif namun akan menghasilkan struktur yang lebih boros karena hasil analisisnya yang sangat konservatif.

\section{KESIMPULAN}

Berdasarkan data-data dan pembahasan maka kesimpulan analisis kapasitas nominal pelat komposit beton-dek baja dengan metode ultimate, tegangan kerja dan SDI-ANSI adalah sebagai berikut.

1. Metode tegangan kerja dengan faktor reduksi $\phi=0,65$ sesuai SNI 2847:2019 merupakan metode paling akurat dalam menganalisis kapasitas nominal lentur pelat komposit beton-dek baja, sehingga metode ini direkomendasikan.

2. Metode ultimate tidak dapat digunakan untuk menganalisis kapasitas nominal pelat komposit beton-dek baja.

3. Metode SDI-ANSI dapat digunakan sebagai alternatif yang konservatif dengan faktor reduksi $\phi=0,85$.

4. Perlu pengujian pelat komposit beton-dek baja tanpa penghubung geser dengan mutu beton minimal $20 \mathrm{MPa}$. 


\section{DAFTAR PUSTAKA}

Amalia, Z., Huzaim, dan S, B. (2014). "Analisis Perilaku Pelat Komposit Floor Deck Beton Ringan Busa dengan kuat tekan $25 \mathrm{MPa}, 30 \mathrm{MPa}$, dan 35 MPa". Tugas Akhir. Universitas Syah Kuala Darussalam.

Blue Scope Lysagth Indonesia. (2008). "SMARTDEK". Blue Scope Lysagth Indonesia. Bekasi.

Badan Standarisasi Nasional. (2019). "Persyaratan Beton Struktural untuk Bangunan Gedung SNI 2847-2019". Badan Standarisasi Nasional (BSN). Jakarta.

Fastaria, R. dan Putri, Y. E. (2014). "Analisa Perbandingan Metode Halfslab dan Plat Komposit Bondek Pekerjaan Struktur Plat Lantai Proyek Pembangunan Apartement De Papilio Tamansari Surabaya". Jurnal Teknik ITS, Vol. 3, No. 2, pp. 41-46.

Irnada, C. R., Huzaim, dan Bermansyah, S. (2014). "Analisis Perilaku Pelat Lantai Komposit Floor Deck Beton Ringan Busa Mutu $35 \mathrm{MPa}$ dengan Ketebalan $10 \mathrm{~cm}, 12 \mathrm{Cm}$, dan 14 $\mathrm{cm}$ ". Tugas Akhir. Universitas Syah Kuala Darussalam.

Kadir, A. M. dan Sudarmadi. (2008). "Perilaku dan Kekuatan Pelat Lantai Komposit Beton-Metal Deck Terhadap Beban Lentur". Majalah Ilmiah BPPT M.P.I, Vol. 2, No. 3, pp. 232-240.

Muliater, M., Tarigan, J., dan Roesyanto. (2018). "Analisis Lendutan dan Slip Pada Pelat Komposit Veton-Metal Deck Berdasarkan Perilaku Uji Statik". Konferensi Nasional Teknik Sipil 12, (hal. 155-164). Batam.

Widhiawati, I. A. R., Yana, A. A., dan Asmara, A. A. (2010). "Analisa Biaya Pelaksanaan Antara Pelat Konvensional dan Sistem Pelat Menggunakan Metal Deck". Jurnal
Ilmiah Teknik Sipil, Vol. 14, No. 1, pp. 20-27.

SDI-ANSI. (2011). "C-2011- Standard For Composite Steel Floor Deck-Slabs". Steel Door Institute. Ohio.

SDI-ANSI. (2017). "C-2017-2017 Standard For Composite Steel Floor DeckSlabs". Steel Door Institute. Ohio.

Segui, W. T. (2007). "Steel Design". Nelson. Toronto.

Siregar, R. M. (2010). "Perbandingan Hasil Perancangan Pelat Beton Pracetak Dengan Pelat Beton Komposit Steel Deck Serta Tinjauan Balok Beton Pracetak Pada Gedung Rumah Sakit Akademik UGM". Program Swadaya Jurusan Teknik Sipil dan Lingkungan Fakultas Teknik UGM. Yogyakarta.

Widjaja, B. R. (1997). "Analysis And Design of Steeldeck-Concrete Composite Slab". Virginia Polytechnic Institute and State University. Virginia. 